\title{
KLASIFIKASI EKSPRESI WAJAH MENGGUNAKAN BAG OF VISUAL WORDS
}

\author{
Muhathir \\ Teknik Informatika, Fakultas Teknik, Universitas Medan Area \\ e-mail: muhathirbangdes@gmail.com
}

\begin{abstract}
Abstrak - Pada hakikatnya, manusia dapat membedakan pola terhadap suatu objek berdasarkan bentuk visual yang mengandung keadaan emosional. Seperti membedakan ekspresi wajah seseorang pada suatu citra. Manusia dapat membedakan ekspresi pada citra tersebut secara kasat mata. Namun komputer yang tidak dapat mengenali ekspresi wajah tersebut. Bag of visual words merupakan suatu skema untuk mengklasifikasikan citra berdasarkan nilai-nilai pixel pada citra. Dengan menggunakan deteksi interest point dan ekstraksi interest point, bag of visual words mengambil ciri unik pada citra sehingga dapat membedakan pola-pola yang terdapat pada suatu citra. Bag of visual word dengan nilai $\mathrm{K} 500 \mathrm{mampu}$ mengklasifikasi pola ekspresi wajah dengan tingkat akurasi $69 \%$,
\end{abstract}

Kata kunci: Wajah, Klasifikasi, Speed-up Robust Feature, Bag of visual words, Ekspresi

\section{PENDAHULUAN}

Pengenalan pola (pattern recognition) adalah salah satu ilmu yang digunakan untuk mengklasifikasikan sesuatu berdasarkan pengukuran kuantitatif fitur (ciri) atau sifat utama dari suatu obyek [1]. sedangkan pola yaitu suatu entitas yang dapat diidentifikasi contoh : raut wajah, sidik jari, gelombang suara, tulisan tangan dan lain sebagainya.

Menurut [2],[3] pendekatan pengenalan pola dapat dikategorikan menjadi tiga jenis : pengenalan pola statistikal, pengenalan pola sintaktik, pengenalan pola neural. Pengukuran yang menunujukkan karakteristik statistkal pola yang ada dengan asumsi pola tersebut diperoleh dari hasil probabilistik, pengenalan pola ini dikenal dengan pengenalan pola statistikal. Pendekatan sintaktik adalah suatu pendekatan yang hanya menganalisis struktur pola dan kontur (tepi batas) objek dari citra. Pendekatan yang ketiga yaitu gabungan dari statistik dan sintaktik atau dikenal sebagai pengenalan pola neural, pendekatan ini merupakan bagian dari jaringan saraf tiruan untuk mengidentifikasi pola. Sehingga semakin sering sistem dilatih maka semakin cerdas pula sistem yang dihasilkan.

Pada hakikatnya, manusia dapat membedakan pola terhadap suatu objek berdasarkan bentuk visual yang mengandung keadaan emosional. Seperti membedakan ekspresi wajah seseorang pada suatu citra. Manusia dapat membedakan ekspresi pada citra tersebut secara kasat mata. Namun komputer yang tidak dapat mengenali ekspresi wajah tersebut. Karena komputer hanya mengenali angka 0 dan 1 .

Bag of visual words merupakan suatu skema untuk mengklasifikasikan citra berdasarkan nilai-nilai pixel pada citra [4] Dengan menggunakan deteksi interest point dan ekstraksi interest point, bag of visual words mengambil ciri unik pada citra sehingga dapat membedakan pola-pola yang terdapat pada suatu citra. Wajah manusia memainkan peran sentral dalam interaksi sosial, oleh karena itu tidak mengherankan bahwa pemrosesan informasi wajah otomatis merupakan subfield penting dan sangat aktif dalam penelitian pengenalan pola [5].

Wajah menampilkan berbagai informasi yang rumit tentang identitas, usia, jenis kelamin, ras dan keadaan emosional dan perhatian. Salah satunya adalah ekspresi wajah. Ekspresi merupakan suatu ungkapan perasaan, yang dapat ditunjukkan melalui suatu gerakan, baik itu gerakan tangan, kaki, suara maupun wajah. Penelitian ini bertujuan untuk mengukur performansi klasifikasi wajah menggunakan bag of visual words. Dimana pada penelitianpenelitian sebelumnya, ditemukan masalah dalam menentukan jumlah nilai k pada clustering fitur citra pada skema bag of visual words.

Dalam prosesnya skema bag of visual words mempunyai 4 tahapan pada klasifikasi diantaranya; menggunakan metode deteksi interest point dan ekstraksi interest point, pengklusteran fitur menggunakan k-means algorithm, pembentukan histogram generation dan klasifikasi menggunakan support vector machine sebagai klasifier (SVM) [6].

Pada peneltian [13] mengggunakan metode speed-up robust feature (SURF) untuk mendeteksi interest point dan ekstraksi interest point. Pada penelitian lainnya [11] menerangkan bahwasanya SURF lebih efisien digunakan sebagai deteksi dan ekstraksi interest point. Untuk itu dalam penelitian ini juga akan digunakan deteksi dan ekstraksi interest point SURF.

\section{A. Bag of Visual words}

Pada dasarnya terdapat 4 tahapan dalam bag of visual words:

- Deteksi dan ekstraksi fitur menggunakan SURF 
- Mengkelompokkan hasil ekstraksi fitur ke dalam cluster (vocabulary) menggunakan kuantisasi vector menggunakan algoritma $\mathrm{k}$-means

- Membentuk Histogram generation terhadap cluster yang telah dibentuk.

- Mengklasifikasikan citra berdasarkan cluster yang telah dibentuk menggunakan support vector machine (SVM).

Tujuan daripada skema bag of visual words ini untuk memaksimalkan akurasi klasifikasi dan meminimalkan komputasi.

\section{B. Speed-up Robust Feature (SURF)}

Penentuan interest point pada SURF menggunakan matrix hessian, dimana matrix hessian didefenisikan sebagai berikut: [10]

$$
H(X, \sigma)=\left[\begin{array}{ll}
L_{x x}(X, \sigma) & L_{x y}(X, \sigma) \\
L_{x y}(X, \sigma) & L_{y y}(X, \sigma)
\end{array}\right]
$$

dimana $L_{-} \mathrm{xx}(\mathrm{X}, \sigma)=\partial^{\wedge} 2 \mathrm{~g}(\sigma) / \partial^{\wedge} 2 \mathrm{x}$ adalah konvolusi dari orde kedua derivatif Gaussian dengan input citra pada point $\mathrm{X}=(\mathrm{x}, \mathrm{y})$, dan serupa untuk L_yy $(\mathrm{X}, \sigma)$. Dengan pendekatan perkiraan adalah $D_{x x^{\prime}} D_{y y^{\prime}}$ dan $D_{x y^{\prime}}$ dimana determinan hessian [7].

$\frac{\left|\operatorname{Lxy}(1,2)\left\|_{F}\right\| D x x(9)\right|_{F}}{|\operatorname{Lxx}(1,2)|_{F} \|\left. D x y(9)\right|_{F}}=0.912 . . \cong 0.9$,

dimana $\left.|| x\right|_{F}$ adalah norma frobenius yang menghasilkan ; [7]

$$
\left.\operatorname{Det}\left(H_{\text {approx }}\right)=D_{x x} D_{y y}-(0.9) D_{x y}\right)^{2}
$$

\section{K-means algorithm}

K-means adalah algoritma pengelompokan partial sederhana berbasis prototipe yang mencoba menemukan gugus $\mathrm{K}$ yang tidak tumpang tindih. Kelompok-kelompok ini diwakili oleh centroids mereka (centroid cluster biasanya adalah mean dari titik-titik di cluster itu). Proses pengelompokan K-means adalah sebagai berikut. Pertama, centroid $\mathrm{K}$ awal dipilih, di mana $\mathrm{K}$ ditentukan oleh pengguna dan menunjukkan jumlah cluster yang diinginkan. Setiap titik dalam data kemudian ditugaskan ke centroid terdekat, dan setiap koleksi titik yang ditugaskan ke centroid membentuk sebuah cluster. Centroid dari setiap cluster kemudian diperbarui berdasarkan titik-titik yang ditugaskan ke cluster tersebut. Proses ini diulang sampai tidak ada titik perubahan cluster [8]. K-means dapat dinyatakan dengan fungsi objektif yang bergantung pada proximities titik data ke centroid cluster seperti berikut:

$$
j=\sum_{j=1}^{k} \sum_{\text {all } i}\left|x_{i}^{j}-c^{j}\right|^{2}, \text { pada kelas } \mathrm{j}
$$

Dimana $c_{k}$ menyatakan koordinat vektor dari $\mathrm{j}^{\mathrm{th}}$ kluster dan $\left\{x_{i}^{j}\right\}$ adalah point yang ditetapkan kepada $j^{\text {th }}$ kluster.

\section{Histogram Generation}

Tujuan dari bag of visual words adalah mendapatkan histogram yang bisa mewakili gambar yang diberikan. Oleh karena itu, persiapan akhir kami untuk klasifikasi citra adalah histogram untuk semua gambar di dalam imageset yang digunakan [12]. Histogram sendiri adalah alur dari frekuensi relatif dari peristiwa masing-masing nilai pixel yang diizinkan pada citra terhadap nilai-nilai itu sendiri [9].

\section{E. Support Vector Machine}

Support vector machine (SVM) adalah algoritma yang menggunakan pemetaan nonlinier untuk mentransformasikan data pelatihan asli ke dimensi yang lebih tinggi. Dalam dimensi baru ini, ia mencari linier pemisah linier yang linier (yaitu, "batas keputusan" yang memisahkan tupel dari satu kelas dari kelas yang lain). Dengan pemetaan nonlinear yang sesuai dengan dimensi yang cukup tinggi, data dari dua kelas selalu dapat dipisahkan oleh hyperplane. SVM menemukan hyperplane ini menggunakan vektor pendukung (tupel pelatihan "esensial") dan margin (ditentukan oleh vektor pendukung) [10]. Pada klasifikasi ekpresi wajah penelitian ini, svm berfungsi sebagai classifier terhadap citra dan fitur yang telah dibentuk.

\section{METODE}

\section{A. Datasheet}

Data yang digunakan dalam penelitian ini yaitu citra wajah berekspresi (Bahagia, Marah, Jijik, Takut, Netral, Sedih, Terkejut) dengan ukuran 256x256. File citra yang digunakan untuk pelatihan maupun pengujian diambil dari situs http://www.kasrl.org/jaffeimages.zip.

\section{B. Langkah Penelitian}

Langkah penelitian secara umum yang dibangun dalam penelitian ini diilustrasikan pada Gambar 1

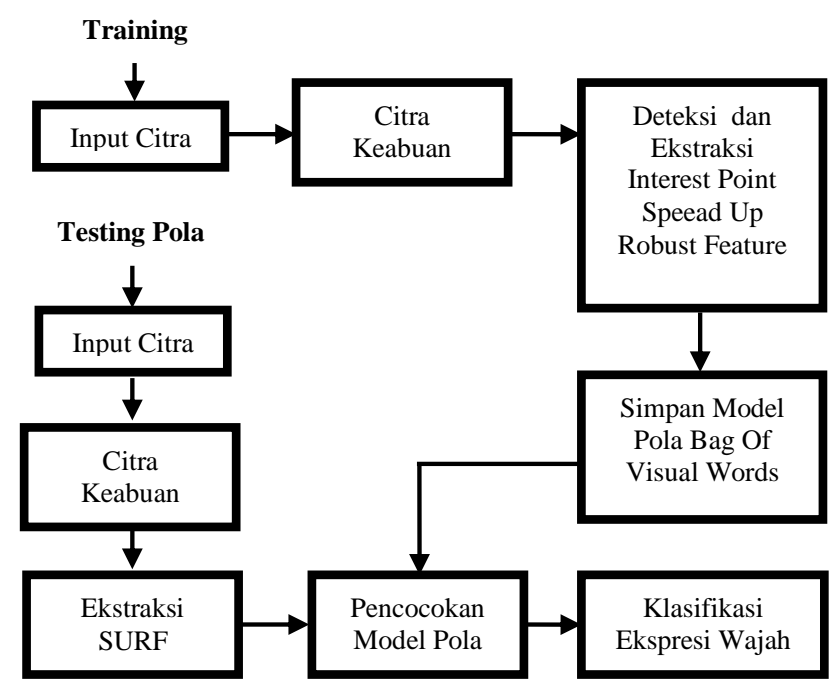




\section{Gambar 1. Langkah Penelitian Secara Umum}

Pada Gambar 1 terdapat dua buah proses yaitu proses training dan proses testing, pada proses training citra inputan dilakukan pre-procesing dengan grayscale dan dilanjutkan dengan mengekstraksi fitur dari citra ekspresi wajah mengunalan SURF dan model pola yang telah diekstrak akan disimpan dalam Bag Of Visual Words, sedangkan pada tahapan testing, citra inputan dilakukan pre-procesing dengan grayscale dan di ekstrak menggunakan SURF kemudian dilanjutkan ketahapan pengklasifikasian model pola yang terdapat pada Bag Of Visual Words menggunakan SVM, jika pola mirip atau mendekati pola training maka output dari klasifikasi yaitu hasil ekspresi wajah .

Langkah penelitan secara keseluruhan pengenalan pola ekspresi wajah yang dibangun dalam penelitian ini diilustrasikan pada Gambar 2.

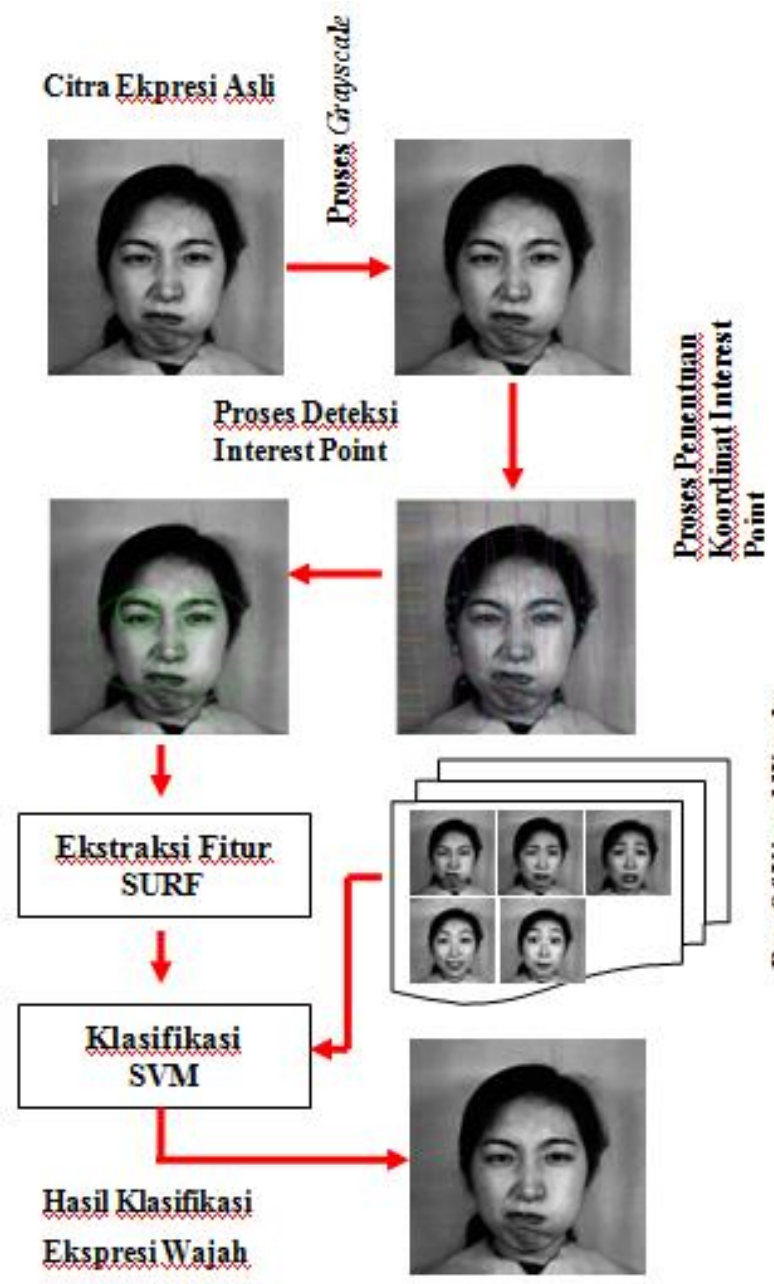

Gambar 2. Langkah Penelitan SURF
Pada langkah penelitian ini yang dikerjakan oleh sistem setelah sistem menerima inputan citra maka sistem akan memproses citra input menjadi grayscale yang gunanya untuk mempermudah perhitungan dimana citra input mempunyai tiga kanal yaitu kanar R, kanal G dan kanal B setelah grayscale bekerja maka citra akan menjadi satu kanal yaitu kanal grayscale, kemudian citra grayscale diproses kembali untuk menentukan koordinat interest point dan mendeteksi pola-pola interest point yang gunanya untuk dapat membangkitkan value dari pola ekspresi wajah, setelah pola interest point terdeteksi pola tersebut akan di ekstrak menggunakan ekstraksi fitur SUFR, bobot dari ekstaksi fitur testing akan diklasfikasikan terhadap bobot ekstaksi fitur training menggunakan SVM.

\section{HASIL DAN PEMBAHASAN}

\section{A. Sampel pelatihan pola ekspresi wajah}

Sampel pelatihan pola ekspresi wajah yang digunakan dalam penelitian ini berjumlah 128 citra wajah yang mewakili ekpresi Bahagia, Marah, Jijik, Takut, Netral, Sedih, dan Terkejut. Gambar 4.1 melampirkan beberapa sampel pola ekspresi wajah yang digunakan sebagai pelatihan.

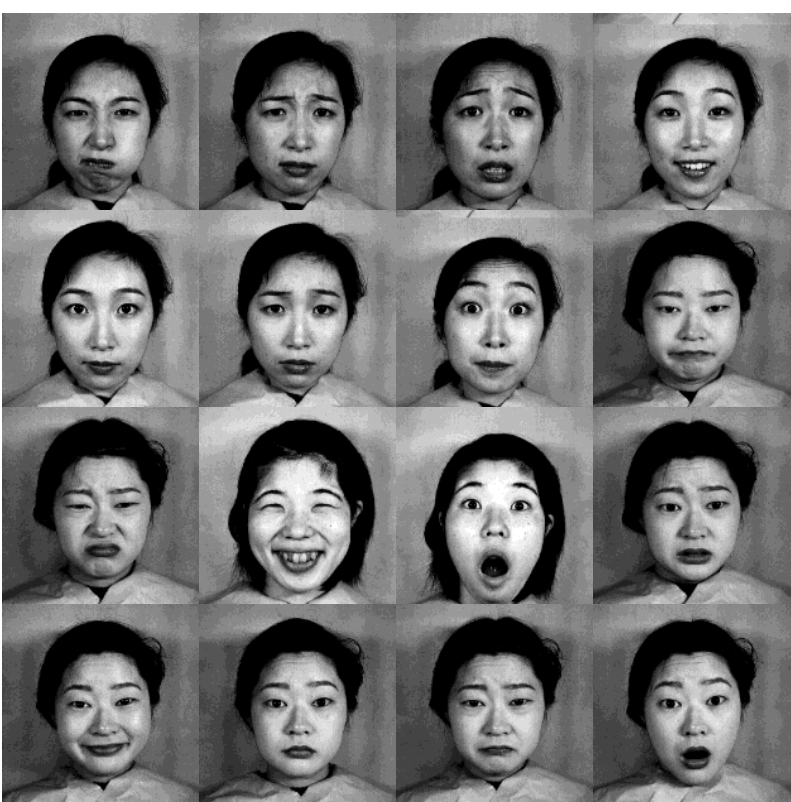

Gambar 3. Sampel pelatihan pola ekspresi wajah yang digunakan

\section{B. Penentuan Koordinat dan Deteksi Interest Point}

Penentuan koordinat interest point dimulai dengan pembentukan grid pada citra dengan menggunakan grid step 8 yang gunanya untuk mengatur jarak koordinat $\mathrm{x}$ (width) dan y (height), dimana koordinat penentuan Interest Point selanjutnya akan berjarak 8 pixel. 


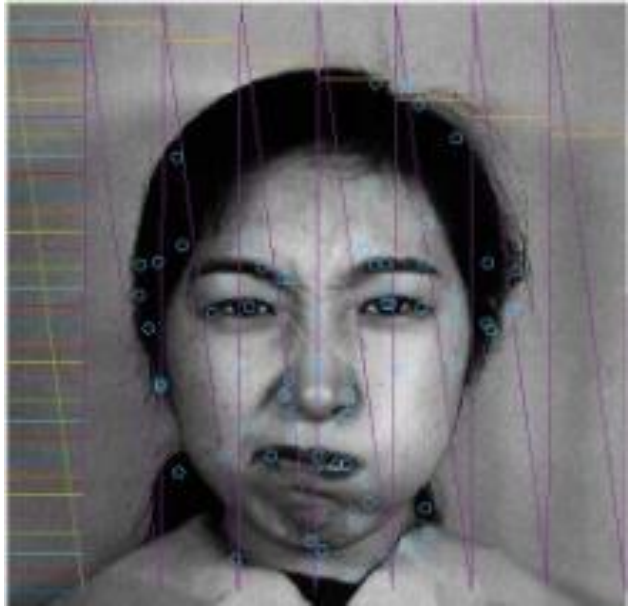

Gambar 4. Penentuan koordinat interest point

Pada gambar 4 dapat dilihat hasil dari penentuan koordinat interest point, dimana perpindahan koordinat disesuaikan dengan penentuan grid stepnya, pada gambar 4 grid step yang digunakan 8 , sehingga terlihat jelas hasil garis pembatas dari penentuan koordinat interest point. Gambar 5 dapat dilihat hasil dari pendeteksian interest point.

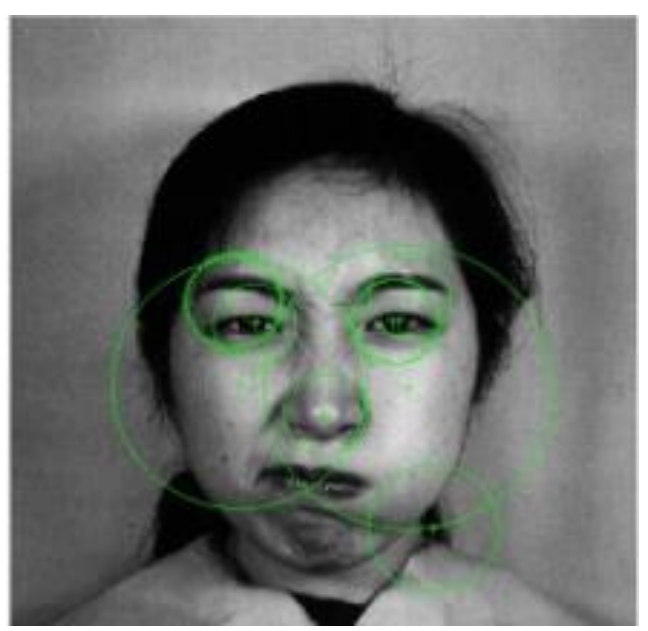

Gambar 5. Hasil deteksi pola interest point

Setiap pola ekspresi wajah memiliki tingkat kejenuhan masing-masing, sehingga hasil dari pendeteksian interest point pun berbeda-beda, pada gambar 5 terdapat beberapa pola hasil pendeteksian interest point yang mewakilkan value daripada citra ekspresi wajah tersebut.

\section{Pengujian dengan variasi jumlah kluster}

Klasifikasi menggunakan metode SVM akan di ujicobakan dengan 10 model jumlah kluster pada bag of visual words, model pertama dengan nilai K 100, model kedua dengan nilai K 200, model ketiga dengan nilai $\mathrm{K}$ 300, model keempat dengan nilai K 400 , model kelima dengan nilai $\mathrm{K} 500$, model keenam dengan nilai $\mathrm{K} 600$, model ketujuh dengan nilai K 700 , model kedelapan dengan nilai K 800 , model kesembilan dengan nilai K 900 , model kesepuluh dengan nilai K 1000.

Hasil pengujian dapat dilihat pada tabel 1 sampai dengan tabel 10, untuk memudahkan jenis ekspresi wajah Bahagia, Marah, Jijik, Takut, Netral, Sedih, dan Terkejut dakan disingkat dengan Ba untuk Bahagia, Ma untuk Marah, Ji untuk Jijik, Ta untuk Takut, Ne untuk Netral, Se untuk Sedih, dan Te untuk Terkejut.

Tabel 1. Hasil pengujian dengan nilai K 100

\begin{tabular}{|l|l|l|l|l|l|l|l|}
\hline & $\mathrm{Ba}$ & $\mathrm{Ma}$ & $\mathrm{Ji}$ & $\mathrm{Ta}$ & $\mathrm{Ne}$ & $\mathrm{Se}$ & $\mathrm{Te}$ \\
\hline $\mathrm{Ba}$ & $\mathbf{0 . 8 3}$ & 0 & 0 & 0 & 0.08 & 0 & 0.08 \\
\hline $\mathrm{Ma}$ & 0.17 & $\mathbf{0 . 4 2}$ & 0.25 & 0 & 0.08 & 0.08 & 0 \\
\hline $\mathrm{Ji}$ & 0 & 0.42 & $\mathbf{0 . 3 3}$ & 0 & 0 & 0.25 & 0 \\
\hline $\mathrm{Ta}$ & 0.15 & 0.15 & 0.23 & $\mathbf{0 . 1 5}$ & 0.08 & 0 & 0.23 \\
\hline $\mathrm{Ne}$ & 0.58 & 0 & 0 & 0 & $\mathbf{0 . 3 3}$ & 0 & 0.08 \\
\hline $\mathrm{Se}$ & 0.17 & 0.17 & 0.08 & 0.25 & 0.08 & $\mathbf{0 . 0 8}$ & 0.17 \\
\hline $\mathrm{Te}$ & 0.17 & 0 & 0.17 & 0 & 0 & 0.08 & $\mathbf{0 . 5 8}$ \\
\hline
\end{tabular}

Tabel 2. Hasil pengujian dengan nilai K 200

\begin{tabular}{|l|l|l|l|l|l|l|l|}
\hline & $\mathrm{Ba}$ & $\mathrm{Ma}$ & $\mathrm{Ji}$ & $\mathrm{Ta}$ & $\mathrm{Ne}$ & $\mathrm{Se}$ & $\mathrm{Te}$ \\
\hline $\mathrm{Ba}$ & $\mathbf{0 . 5 0}$ & 0 & 0 & 0.33 & 0.17 & 0 & 0 \\
\hline $\mathrm{Ma}$ & 0 & $\mathbf{0 . 9 2}$ & 0.08 & 0 & 0 & 0 & 0 \\
\hline $\mathrm{Ji}$ & 0 & 0.25 & $\mathbf{0 . 3 3}$ & 0.17 & 0.17 & 0.08 & 0 \\
\hline $\mathrm{Ta}$ & 0 & 0.23 & 0.23 & $\mathbf{0 . 2 3}$ & 0 & 0.08 & 0.23 \\
\hline $\mathrm{Ne}$ & 0.08 & 0 & 0.17 & 0.8 & $\mathbf{0 . 4 2}$ & 0 & 0.25 \\
\hline $\mathrm{Se}$ & 0.25 & 0.08 & 0.25 & 0.25 & 0.08 & $\mathbf{0}$ & 0.08 \\
\hline $\mathrm{Te}$ & 0.33 & 0 & 0 & 0 & 0 & 0.08 & $\mathbf{0 . 5 8}$ \\
\hline
\end{tabular}

Tabel 3. Hasil pengujian dengan nilai K 300

\begin{tabular}{|l|l|l|l|l|l|l|l|}
\hline & $\mathrm{Ba}$ & $\mathrm{Ma}$ & $\mathrm{Ji}$ & $\mathrm{Ta}$ & $\mathrm{Ne}$ & $\mathrm{Se}$ & $\mathrm{Te}$ \\
\hline $\mathrm{Ba}$ & $\mathbf{0 . 4 2}$ & 0.17 & 0 & 0 & 0.33 & 0.08 & 0 \\
\hline $\mathrm{Ma}$ & 0.08 & $\mathbf{0 . 6 7}$ & 0.08 & 0.08 & 0.08 & 0 & 0 \\
\hline $\mathrm{Ji}$ & 0 & 0.33 & $\mathbf{0 . 2 5}$ & 0.42 & 0 & 0 & 0 \\
\hline $\mathrm{Ta}$ & 0 & 0.08 & 0.15 & $\mathbf{0 . 3 1}$ & 0.31 & 0.08 & 0.08 \\
\hline $\mathrm{Ne}$ & 0.25 & 0 & 0 & 0.25 & $\mathbf{0 . 5 0}$ & 0 & 0 \\
\hline $\mathrm{Se}$ & 0.08 & 0 & 0.08 & 0.08 & 0.42 & $\mathbf{0 . 0 8}$ & 0.25 \\
\hline $\mathrm{Te}$ & 0.08 & 0 & 0 & 0 & 0.08 & 0.08 & $\mathbf{0 . 7 5}$ \\
\hline
\end{tabular}

Tabel 4. Hasil pengujian dengan nilai K 400

\begin{tabular}{|l|l|l|l|l|l|l|l|}
\hline & $\mathrm{Ba}$ & $\mathrm{Ma}$ & $\mathrm{Ji}$ & $\mathrm{Ta}$ & $\mathrm{Ne}$ & $\mathrm{Se}$ & $\mathrm{Te}$ \\
\hline $\mathrm{Ba}$ & $\mathbf{0 . 9 2}$ & 0 & 0.08 & 0 & 0 & 0 & 0 \\
\hline $\mathrm{Ma}$ & 0 & $\mathbf{0 . 6 7}$ & 0.08 & 0 & 0.08 & 0.08 & 0.08 \\
\hline $\mathrm{Ji}$ & 0 & 0.08 & $\mathbf{0 . 7 5}$ & 0.17 & 0 & 0 & 0 \\
\hline $\mathrm{Ta}$ & 0.15 & 0 & 0 & $\mathbf{0 . 3 1}$ & 0.08 & 0.31 & 0.15 \\
\hline $\mathrm{Ne}$ & 0.17 & 0.08 & 0 & 0 & $\mathbf{0 . 6 7}$ & 0.08 & 0 \\
\hline $\mathrm{Se}$ & 0.25 & 0.17 & 0.08 & 0 & 0 & $\mathbf{0 . 3 3}$ & 0.17 \\
\hline $\mathrm{Te}$ & 0.08 & 0 & 0.08 & 0 & 0 & 0 & $\mathbf{0 . 8 3}$ \\
\hline
\end{tabular}

Tabel 5. Hasil pengujian dengan nilai K 500

\begin{tabular}{|l|l|l|l|l|l|l|l|}
\hline & $\mathrm{Ba}$ & $\mathrm{Ma}$ & $\mathrm{Ji}$ & $\mathrm{Ta}$ & $\mathrm{Ne}$ & $\mathrm{Se}$ & $\mathrm{Te}$ \\
\hline $\mathrm{Ba}$ & $\mathbf{0 . 7 5}$ & 0.08 & 0.08 & 0 & 0.08 & 0 & 0 \\
\hline $\mathrm{Ma}$ & 0 & $\mathbf{0 . 5 8}$ & 0.25 & 0 & 0.08 & 0.08 & 0 \\
\hline $\mathrm{Ji}$ & 0 & 0 & $\mathbf{1 . 0}$ & 0 & 0 & 0 & 0 \\
\hline
\end{tabular}




\begin{tabular}{|l|l|l|l|l|l|l|l|}
\hline $\mathrm{Ta}$ & 0 & 0 & 0.23 & $\mathbf{0 . 6 9}$ & 0 & 0 & 0.08 \\
\hline $\mathrm{Ne}$ & 0 & 0 & 0 & 0 & $\mathbf{0 . 8 3}$ & 0.08 & 0.08 \\
\hline $\mathrm{Se}$ & 0 & 0.25 & 0.08 & 0.08 & 0.17 & $\mathbf{0 . 0 8}$ & 0.33 \\
\hline $\mathrm{Te}$ & 0 & 0 & 0 & 0 & 0 & 0.08 & $\mathbf{0 . 9 2}$ \\
\hline
\end{tabular}

Tabel 6. Hasil pengujian dengan nilai K 600

\begin{tabular}{|l|l|l|l|l|l|l|l|}
\hline & $\mathrm{Ba}$ & $\mathrm{Ma}$ & $\mathrm{Ji}$ & $\mathrm{Ta}$ & $\mathrm{Ne}$ & $\mathrm{Se}$ & $\mathrm{Te}$ \\
\hline $\mathrm{Ba}$ & $\mathbf{0 . 6 7}$ & 0 & 0 & 0 & 0.08 & 0.17 & 0.08 \\
\hline $\mathrm{Ma}$ & 0.08 & $\mathbf{0 . 5 8}$ & 0 & 0.08 & 0 & 0.25 & 0 \\
\hline $\mathrm{Ji}$ & 0.17 & 0 & $\mathbf{0 . 4 2}$ & 0.25 & 0 & 0 & 0.17 \\
\hline $\mathrm{Ta}$ & 0.08 & 0 & 0.15 & $\mathbf{0 . 4 6}$ & 0 & 0 & 0.31 \\
\hline $\mathrm{Ne}$ & 0 & 0 & 0 & 0.17 & $\mathbf{0 . 7 5}$ & 0 & 0.08 \\
\hline $\mathrm{Se}$ & 0.25 & 0.08 & 0.08 & 0.08 & 0.17 & $\mathbf{0 . 2 5}$ & 0.08 \\
\hline $\mathrm{Te}$ & 0.08 & 0 & 0 & 0.17 & 0 & 0 & $\mathbf{0 . 7 5}$ \\
\hline
\end{tabular}

Tabel7. Hasil pengujian dengan nilai K 700

\begin{tabular}{|l|l|l|l|l|l|l|l|}
\hline & $\mathrm{Ba}$ & $\mathrm{Ma}$ & $\mathrm{Ji}$ & $\mathrm{Ta}$ & $\mathrm{Ne}$ & $\mathrm{Se}$ & $\mathrm{Te}$ \\
\hline $\mathrm{Ba}$ & $\mathbf{0 . 5 0}$ & 0.17 & 0 & 0 & 0.33 & 0 & 0 \\
\hline $\mathrm{Ma}$ & 0.08 & $\mathbf{0 . 6 7}$ & 0.08 & 0 & 0.08 & 0.08 & 0 \\
\hline $\mathrm{Ji}$ & 0.17 & 0.25 & $\mathbf{0 . 3 3}$ & 0.08 & 0.17 & 0 & 0 \\
\hline $\mathrm{Ta}$ & 0.15 & 0 & 0.08 & $\mathbf{0 . 3 8}$ & 0.08 & 0.08 & 0.23 \\
\hline $\mathrm{Ne}$ & 0.33 & 0 & 0 & 0.17 & $\mathbf{0 . 5 0}$ & 0 & 0 \\
\hline $\mathrm{Se}$ & 0.25 & 0.08 & 0.17 & 0 & 0 & $\mathbf{0 . 3 3}$ & 0.17 \\
\hline $\mathrm{Te}$ & 0 & 0 & 0 & 0 & 0 & 0.25 & $\mathbf{0 . 7 5}$ \\
\hline
\end{tabular}

Tabel 8. Hasil pengujian dengan nilai K 800

\begin{tabular}{|l|l|l|l|l|l|l|l|}
\hline & $\mathrm{Ba}$ & $\mathrm{Ma}$ & $\mathrm{Ji}$ & $\mathrm{Ta}$ & $\mathrm{Ne}$ & $\mathrm{Se}$ & $\mathrm{Te}$ \\
\hline $\mathrm{Ba}$ & $\mathbf{0 . 8 3}$ & 0 & 0 & 0 & 0 & 0.17 & 0 \\
\hline $\mathrm{Ma}$ & 0 & $\mathbf{0 . 6 7}$ & 0.08 & 0 & 0 & 0.25 & 0 \\
\hline $\mathrm{Ji}$ & 0 & 0.25 & $\mathbf{0 . 5 8}$ & 0 & 0 & 0.08 & 0.08 \\
\hline $\mathrm{Ta}$ & 0.08 & 0.08 & 0.08 & $\mathbf{0 . 5 4}$ & 0.08 & 0 & 0.15 \\
\hline $\mathrm{Ne}$ & 0.08 & 0 & 0 & 0 & $\mathbf{0 . 9 2}$ & 0 & 0 \\
\hline $\mathrm{Se}$ & 0 & 0.08 & 0.25 & 0.08 & 0.17 & $\mathbf{0 . 2 5}$ & 0.17 \\
\hline $\mathrm{Te}$ & 0 & 0 & 0 & 0.08 & 0.08 & 0 & $\mathbf{0 . 8 3}$ \\
\hline
\end{tabular}

Tabel 9. Hasil pengujian dengan nilai K 900

\begin{tabular}{|l|l|l|l|l|l|l|l|}
\hline & $\mathrm{Ba}$ & $\mathrm{Ma}$ & $\mathrm{Ji}$ & $\mathrm{Ta}$ & $\mathrm{Ne}$ & $\mathrm{Se}$ & $\mathrm{Te}$ \\
\hline $\mathrm{Ba}$ & $\mathbf{0 . 7 5}$ & 0.08 & 0 & 0 & 0.08 & 0.08 & 0 \\
\hline $\mathrm{Ma}$ & 0 & $\mathbf{0 . 6 7}$ & 0.33 & 0 & 0 & 0 & 0 \\
\hline $\mathrm{Ji}$ & 0.08 & 0 & $\mathbf{0 . 4 2}$ & 0.25 & 0 & 0.25 & 0 \\
\hline $\mathrm{Ta}$ & 0.08 & 0 & 0.23 & $\mathbf{0 . 3 8}$ & 0.15 & 0 & 0.15 \\
\hline $\mathrm{Ne}$ & 0.08 & 0 & 0 & 0 & $\mathbf{0 . 6 7}$ & 0.17 & 0.08 \\
\hline $\mathrm{Se}$ & 0.08 & 0.25 & 0.25 & 0 & 0 & $\mathbf{0 . 3 3}$ & 0.08 \\
\hline $\mathrm{Te}$ & 0 & 0 & 0 & 0 & 0 & 0 & $\mathbf{1 . 0}$ \\
\hline
\end{tabular}

Tabel 10. Hasil pengujian dengan nilai K 1000

\begin{tabular}{|l|l|l|l|l|l|l|l|}
\hline & $\mathrm{Ba}$ & $\mathrm{Ma}$ & $\mathrm{Ji}$ & $\mathrm{Ta}$ & $\mathrm{Ne}$ & $\mathrm{Se}$ & $\mathrm{Te}$ \\
\hline $\mathrm{Ba}$ & $\mathbf{0 . 5 8}$ & 0.08 & 0 & 0 & 0.33 & 0 & 0 \\
\hline $\mathrm{Ma}$ & 0 & $\mathbf{0 . 7 2}$ & 0.17 & 0 & 0.08 & 0 & 0 \\
\hline $\mathrm{Ji}$ & 0 & 0.25 & $\mathbf{0 . 5 0}$ & 0.25 & 0 & 0 & 0 \\
\hline $\mathrm{Ta}$ & 0.08 & 0.08 & 0 & $\mathbf{0 . 4 6}$ & 0 & 0.08 & 0.31 \\
\hline $\mathrm{Ne}$ & 0.08 & 0 & 0.17 & 0.08 & $\mathbf{0 . 5 8}$ & 0.08 & 0 \\
\hline $\mathrm{Se}$ & 0 & 0.33 & 0.17 & 0 & 0.25 & $\mathbf{0 . 2 5}$ & 0 \\
\hline $\mathrm{Te}$ & 0 & 0 & 0 & 0.08 & 0 & 0 & $\mathbf{0 . 9 2}$ \\
\hline
\end{tabular}

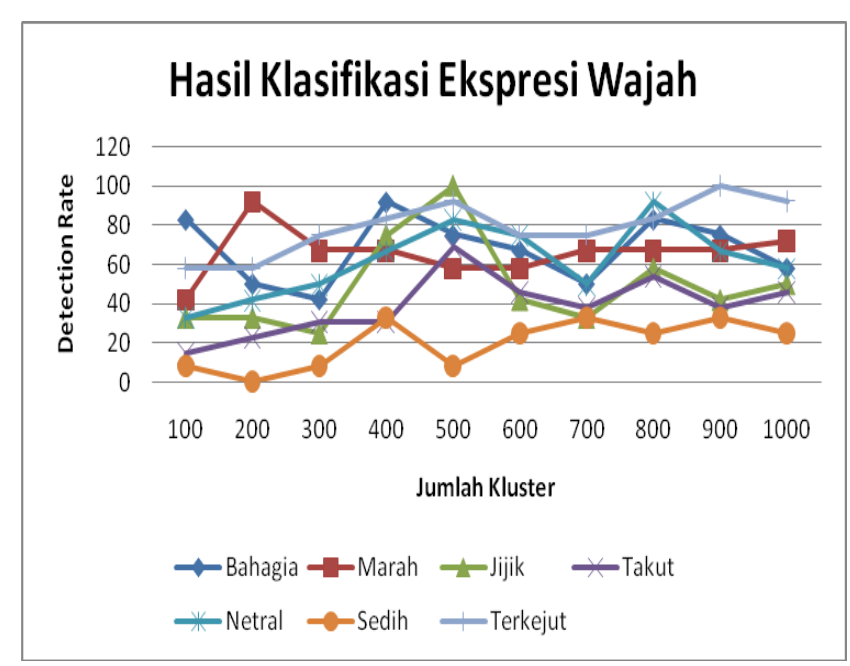

Gambar 6. Hasil Klasifikasi SVM

Pada gambar 6, grafik mengilustrasikan hasil klasifikasi ekspresi wajah menggunakan SVM dengan kategori K 100 s/d K 1000, pada ekspresi wajah terkejut SVM mampu mengklasifikasi dengan baik yaitu dengan rata-rata tingkat akurasi $79.1 \%$, pada ekspresi bahagia SVM mampu mengklasifikasi dengan rata-rata tingkat akurasi $67.5 \%$, pada ekspresi marah SVM mampu mengklasifikasi dengan rata-rata tingkat akurasi $65.7 \%$, pada ekspresi netral SVM mampu mengklasifikasi dengan rata-rata tingkat akurasi $61.7 \%$, pada ekspresi jijik SVM mampu mengklasifikasi dengan rata-rata tingkat akurasi $49.1 \%$, pada ekspresi takut SVM mampu mengklasifikasi dengan rata-rata tingkat akurasi $39.1 \%$, sedangkan pada ekspresi sedih SVM hanya mampu mengklasifikasi dengan rata-rata tingkat akurasi $19.8 \%$.

Dari tabel $1 \mathrm{~s} / \mathrm{d} 10$ menunjukkan klasifikasi dengan akurasi bervariasi untuk masing-masing jumlah nilai kluster.

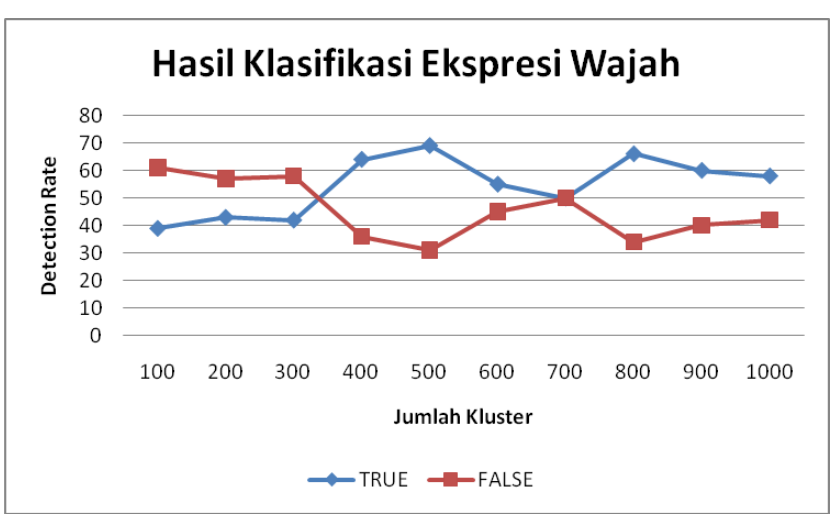

Gambar 7. Hasil Klasifikasi berdasarkan jumlah kluster

pada nilai K 100 memperoleh tingkat akurasi yang begitu rendah yaitu dengan rata-rata akurasi 39\%, pada nilai K 500 memperoleh tingkat akurasi yang paling tinggi yaitu dengan rata-rat akurasi $69 \%$, sedangkan pada nilai $\mathrm{K}$ 200 nilai rata-rata akurasi mencapai $43 \%$, pada nilai K 300 nilai rata-rata akurasi mencapai $42 \%$, pada nilai K 400 
nilai rata-rata akurasi mencapai $64 \%$, pada nilai K 600 nilai rata-rata akurasi mencapai $55 \%$, pada nilai K 700 nilai rata-rata akurasi mencapai $50 \%$, pada nilai $\mathrm{K} 800$ nilai rata-rata akurasi mencapai $66 \%$, pada nilai $\mathrm{K} 900$ nilai rata-rata akurasi mencapai $60 \%$, pada nilai K 1000 nilai rata-rata akurasi mencapai 58\%. Penyebab dari rendahnya tingkat akurasi dikarenakan bag of feature memiliki rentang index word yang sangat rapat, gambar 8 menunjukkan kemunculan visual word dengan $\mathrm{K} 100$ dan gambar 9 menunjukkan kemunculan visual word dengan $\mathrm{K}$ 500.

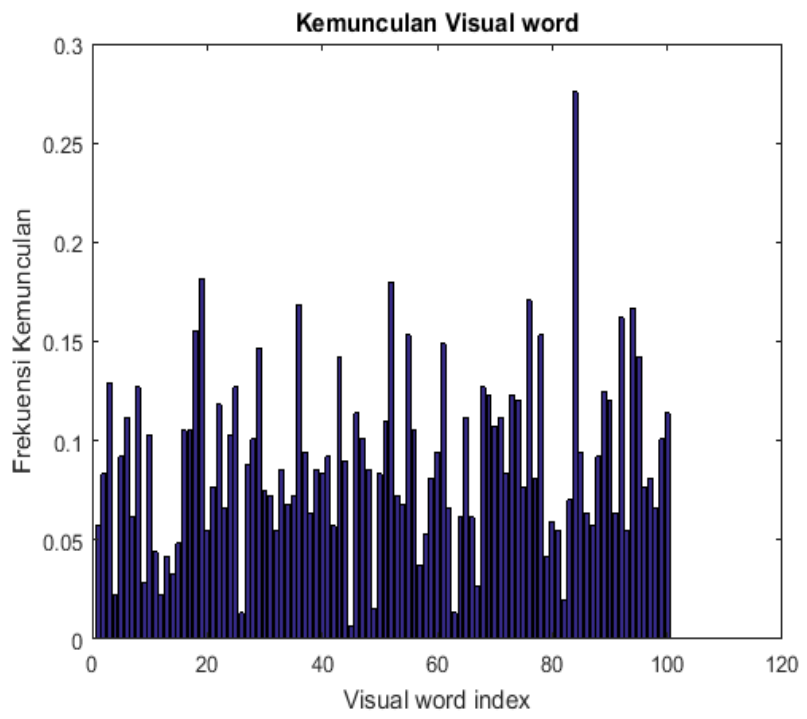

Gambar 8. Kemunculan Visual Word dengan K 100

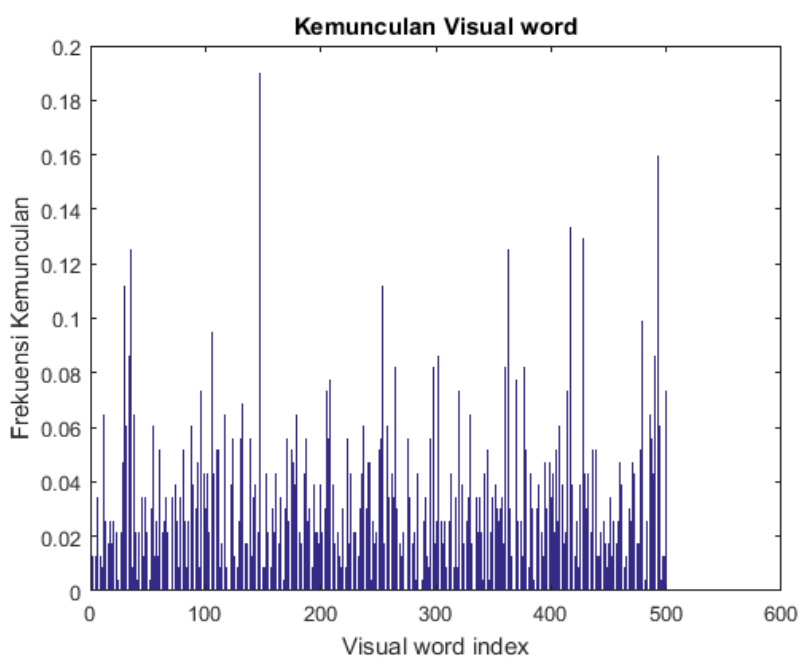

Gambar 9. Kemunculan Visual Word dengan K 500

\section{Pembahasan}

Berdasarkan hasil penelitian yang telah dilakukan, dengan menguji cobakan nilai kluster yang berbeda-beda memperoleh hasil yang belum maksimal, seperti yang ditunjukkan pada gambar 7 , hanya empat pengujian yang memproleh akurasi $>=60 \%$, hal ini berpengaruh dengan tingkat kerenggangan visual word, pada gambar 9 terlihat jelas kerenggangan visual word dengan nilai K 500 yang memperoleh tingkat akurasi tertinggi yaitu 69\%, sedangkan pada gambar 8 terlihat jelas kerapatan visual word dengan nilai K 100 yang hanya memperoleh tingkat akurasi $39 \%$.

\section{KESIMPULAN}

Hasil penelitian menunjukkan bag of visual words masih belum maksimal dalam mengklasifikasi data ekspresi wajah

Untuk meningkatkan kualitas kinerja bag of visual words, dapat menambahkan pendekatan untuk menentukan jumlah $\mathrm{K}$ yang baik dalam mengkluster pola visual words. Penambahan pendekatan tersebut tentunya akan mempengaruhi kecepatan komputasi pada pengenalan pola.

\section{REFERENSI}

[1] Gonzalez, R.C., \& Woods, R.E. 1992. Digital Image Processing. Addison - Wesley Publishing Company, USA

[2] Gonzalez, R.C., \& Woods, R.E. 2008. Digital Image Processing Third Edition. Addison - Wesley Publishing Company, USA.

[3] Anil, K.J \& Robert P.W.D. 2004. Introduction to pattern recognition. (online) http://rduin.nl/papers/PR_Intro.pdf (31 Agustus 2016).

[4] Farhangi, Mohammad Mehdi, Soryani, Mohsen, \& Fathy, Mahmood. 2013. Informative Visual Words Construction to Improve Bag of Words Image Representation. IET Image Process 8(5):310-318.

[5] J.Lyons, Michael, Budynek, Julien \& Akamatsu, Shigeru. 1999 Automatic Classification of Single Facial Images. Pattern Analysis and Machine Intelligence, Vol. 21, pp. 1357-1362.

[6] Azhar, Rizal, Tuwohingide, Kamudi Dasrit, Sarimuddin, Suciati, Nanik. 2015. Batik Image Classification Using SIFT Feature Extraction. The Third Information Systems International Conference.pp. 24-30.

[7] Bay, Herbert, Tuytelaars, Tinne \& Van Gool, Luc. 2006. Surf: Speeded Up Robust Features. $9^{\text {th }}$ European Conference on Computer Vision. 110(3):404-417.

[8] Wu, Junjie. 2012. Advances in K-means Clustering- A Data Mining Thinking. Doctoral Theses- Springer, London.

[9] Salomon, Chris \& Breckon, Toby. 2011. Fundamentals of Digital Image Processing. Wiley-Blackwell: Oxford

[10] Han, Jiawei \& Kamber, Micheline. 2006. Data Mining: Concepts and Techniques. $2^{\text {nd }}$ Edition. Morgan Kaufmann: Amsterdam

[11] Shukla, Tuhin, Mishra, Nishchol \& Sharma, Sanjeev. 2013. Automatic Image Annotation using SURF Features. International Journal Computer Applications 68(4): 17-24B

[12] Kim, Jinho, Kim, Byung-soo, \& Savarese, Silvio. 2012. Classification of Satellite Images based on Scale-Invariant Feature Transform . Proceedings of the International Conference on Image Processing, Computer Vision, and Pattern Recognition (IPCV); Athens.

[13] Cruz-Roa, Angel, C. Caicedo, Juan \& Gonzalez, Fabio A. 2009 Visual Pattern Analysis in Histopathology Images Using Bag of Features. CIARP 2009. Pp 521-528. 